\title{
INVESTIGATION OF THE RELATIONSHIP BETWEEN EARLY MALADAPTIVE SCHEMAS, PSYCHOLOGICAL RESILIENCE AND INTERPERSONAL RELATIONSHIP STYLE IN YOUNG ADULTS CONVERTED FROM THE MASTER'S THESIS.
}

\author{
Selen Öcal ${ }^{1}$, Kahraman Güler ${ }^{2}$ \\ Expert ,Clinical Psychology, İstanbul Aydın University, İstanbul, Turkey ${ }^{1}$ \\ Assistant Professor, Psychology, İstanbul Aydın University, İstanbul, Turkey ${ }^{2}$
}

\begin{abstract}
This study aims to examine the relationship between early maladaptive schemas, interpersonal relationship style, and psychological resilience. The sample of the research consists of 322(208women / 104 men) from Istanbul, Izmir, and Mugla provinces over the age of 18. Sociodemographic Data Sheet, The Young Schema Questionnaire 3 Short form, Interpersonal Relationship Scale, Psychological Resilience Scale were used as a data collection tool. For the application of data collection tools, The Sociodemographic data form, The young schema questionnaire 3 short form, the Interpersonal relationship scale, Psychological resilience scale has been transferred to Google Forms and have been selected by simple random sampling method. The descriptive statistical methods for the analysis of the obtained data, the t-test for the comparison of quantitative data, the Pearson correlation analysis for the relationship between the scale of research and the scale and continuous variable. According to the findings, it was found that a weak and positive relationship was found between the approval-seeking schema and the psychological resilience subdimensions. However, significant negative correlations were found with other schema domains. According to those, it was observed that emotional deprivation and imperfection subscales had a positive effect on the frustrative relationship style. The Approval-seeking subscale had a positive effect on the nurturing relationship style, and the imperfection, failure, and suppression of emotions subscales harmed the nurturing relationship styles.
\end{abstract}

Key Words: Schemas, psychological resilience, interpersonal relationship style, schema therapy.

\section{INTRODUCTİON}

Schema Therapy has recently become a concept that we have come across a lot both scientifically and in our daily lives. This form of therapy, which we are often familiar with, systematically combines many different therapy schools based on the cognitive behavioral therapy model (Masley, Gill Dec, Simpson and Taylor, 2013:186). Schemas can be described as mental structures that develop at an early stage, have a certain feeling, movement, and last a lifetime, and are repeated (Sour and Okan, 2021:527). Schemes, according to Beck; mental structures that process and plan perceived information are also defined as planned forms of thought that continue with the experiences that individuals have acquired in childhood and throughout their life processes (Gör et al., 2017:198). According to this model of therapy, incompatible schemes arise as a result of the failure to meet the basic needs of people at an early stage and continue to have their effect in people's adulthood. Unmet needs in childhood, these individuals be placed in a position secure attachment, autonomy, skill, and negative self-perceptions, needs, it's not like specifying the act to nerve problems, and negative self-regulation(as defined in Thompson 2019: 17). Young and colleagues (2003) have specified five different schema areas that arise as a result of each unmet basic need. These; separation and rejection have been called damaged autonomy, weak boundaries, orientation to others, and excessive alertness and suppression, and it has been revealed that there are a total of 18 early incompatible schemes under these areas of the scheme. These schemes 


\title{
International Advanced Research Journal in Science, Engineering and Technology
}

\author{
Vol. 8, Issue 9, September 2021
}

DOI: 10.17148/IARJSET.2021.8977

are; Abandonment/Instability, Mistrust/Abuse, Emotional deprivation, Defectiveness/Shame, Social isolation, Dependence/Incompetence, Vulnerability to har mor illness, Enmeshment, Entitlement /Grandiosity, Insufficient selfcontrol, Subjugation, Self-sacrifice, Approval-seeking, Pessimism, Emotional inhibition, Unrelenting standards, is called Punishment (Ertürk and Kaynar, 2017:101).

Interpersonal relationships that help people assimilate themselves provide an opportunity to continue the existence of an individual and meet his needs during the communication period that a person establishes with his environment, and therefore it's a need for people (Çelik and Topkaya,2018:140). Plutchik (1997) defined interpersonal relationship as the feeling, thinking and behavior style that individuals experience in the relationship processes that they establish with other people. It has been noted that the ability of these people to perceive themselves, character traits, family style and empathize has an effect on the processes of starting and ending a relationship (Küçükmetin, 2018: 10, quoted from 1996). Every person in relationships has an impact on that relationship. For this reason, it is very effective for people to understand who they are communicating with, how and under what conditions, and how they understand each other. As a result of these effects, interpersonal relationship styles, which are formed personally and may differ, occur (Batigun and Sahin, 2009:6). In research of given literature, interpersonal relationship styles are usually considered as two types. The first of these; able to specify the expectations of the people, they feel they are not being judged makes a positive contribution to their lives and that is nutritious, and the other is a inhibitory style that does not contribute to their lives, negatively affects their communication and is an interpersonal style in which self-centeredness is at the forefront (Koc,2014:164).

A skill that can be developed over time and that people have or should have, which is a psychological facemask, the people in childhood to cope with negative situations that you encounter in the early period of the struggle of people the psychological strength of the person's facemask and positively affect the levels of beginning to build the foundation (Kavi and Karakale,2018: 57). Psychological resilience in general; is also often associated with the fact that people's mood is good and their environment is cultivated or both (Brennan, 2008:56). When the literature is examined, it has been tried to explain the risk and protective factors in the research on robustness, and various risk and protective factors have been indicated. The most common types of risk factors are; low self-esteem, poverty, growing up in a divorced family, violence, and bullying, while protective factors see the most common ones are; the capacity to take responsibility, conscious parents, and having good family communication, human relations are useful and a positive role model import(Gizir,2016:118).

\section{MEETHOD}

\subsection{The Model of the Research}

This study, conducted according to the relational screening model, was conducted with the approval of the Istanbul Aydin University Ethics Committee. Before the data collection stage, the informed consent form was approved for each participant.

\subsection{Participants}

The sample group of the study consists of young adults aged 18-45 who voluntarily agreed to participate in the study. A total of 322 participants, 218 of whom were women (67.7\%) and 104 were men (32.3\%), came from Istanbul, Izmir, Bursa, and Mugla provinces.

\subsection{Data Collection Tools}

In this study, the data were collected by applying the Young schema scale short form-3 (YSE-KFS), Psychological Endurance Scale for Adults, and Interpersonal Relationship Style Scale (KITO), and Personal Information Form.

\subsubsection{Sociodemographic Data Form}

.In the form, participants were asked personal questions such as age, gender, educational level, marital status and income level, and profession. Some of the questions were asked categorically and some were open-ended.

\subsubsection{The Scale of Interpersonal Relationship Decency}

Shahin et al.(1994) the scale developed and conducted by them in the reliability and validity study is a self-assessment scale consisting of 31 items in total, created using a 53-item behavior list found in the manual of the program "Stress Management: A Positive Strategy".

\subsubsection{Young's Scheme Scale Short Form - 3}




\section{International Advanced Research Journal in Science, Engineering and Technology}

Vol. 8, Issue 9, September 2021

DOI: 10.17148/IARJSET.2021.8977

a self-report scale consisting of 90 items, which is the short form of the Young Schema Scale (YSÖ-KF3), which was updated in 2004, was used. Participants are expected to evaluate themselves individually on a Likert-type scale by scoring how much they define themselves between dec and 6 for each item.

\subsubsection{The Scale of Psychological Endurance For Adults}

The translation of the Psychological Resilience Scale for Adults developed by Friborg et al. into Turkish, the validity and reliability study was conducted by Basim and Cetin (2011). English is a five-factor scale consisting of 33 items in total.

\subsection{Data Analysis}

After the data were transferred to the SPPS 25 program, the analyzes were performed. The normality test, which is the first stage of the analysis, has been applied and the skewness and kurtosis values related to the variables have been examined, it is seen that the dec values are between -2 and +2 . According to George and Mallery (2010), it was determined that the skewness and kurtosis values were in the range of -2 to +2 , which is adequate for the normal distribution.

Table 1. Psychological Endurance Scale For Adults, Interpersonal Relationships Scale, Skewness and Kurtosis Values Related to the Young Schema Scale

\begin{tabular}{lll}
\hline & Skewness & Kurtosis \\
\hline The Scale of Psychological Endurance For Adults & -0.155 & -0.330 \\
Self Perception & -0.274 & -0.179 \\
Perception of the Future & -0.424 & -0.505 \\
Structural Style & -0.272 & -0.388 \\
Social Competence & -0.489 & -0.110 \\
Family Harmony & -0.333 & 0.002 \\
Social Resources & -0.323 & -0.636 \\
& & \\
The Scale of Interpersonal Relationships & & \\
Nurturing Relationship Style & -0.491 & -0.031 \\
Toxic Relationship Style & 0.814 & -0.141 \\
& & \\
The Scale of Young Scheme & & \\
Emotional Deprivation & 1.438 & 1.944 \\
Social Isolation/Insecurity & 1.021 & 0.863 \\
Imperfection & 1.477 & 1.803 \\
Suppressing Emotions & 0.811 & 0.256 \\
Nesting/Addiction & 1.263 & 1.628 \\
Abandonment & 1.401 & 1.741 \\
Resilience in the Face of Threats & 0.910 & 0.661 \\
Failure & 1.152 & 1.351 \\
Pessimism & 0.965 & 0.406 \\
Insufficient Self-Control/Self-Discipline & 0.194 & -0.669 \\
Self-sacrifice & 0.372 & -0.624 \\
Punishment & 0.043 & -0.519 \\
High Standards & 0.288 & -0.791 \\
Approval Seeking & -0.025 & -0.717 \\
\hline
\end{tabular}

\section{FINDINGS}


International Advanced Research Journal in Science, Engineering and Technology

Vol. 8, Issue 9, September 2021

DOI: $10.17148 /$ IARJSET.2021.8977

Table 2 . Demographic Characteristics of the Participants

\begin{tabular}{|c|c|c|c|}
\hline & & $\mathbf{n}$ & $\%$ \\
\hline \multirow[t]{3}{*}{ Gender } & Female & 218 & 67.7 \\
\hline & Male & 104 & 32.3 \\
\hline & Total & 322 & 100.0 \\
\hline Duration & of Graduate of Primary School & 36 & 11.2 \\
\hline \multirow[t]{5}{*}{ Education } & Graduate of Middle-School & 32 & 9.9 \\
\hline & High School Graduate & 71 & 22.0 \\
\hline & Graduate & 146 & 45.3 \\
\hline & Postgraduate and Doctorate & 37 & 11.5 \\
\hline & Total & 322 & 100.0 \\
\hline \multirow[t]{3}{*}{ Marital Status } & Married & 141 & 43.8 \\
\hline & Single & 181 & 56.2 \\
\hline & Total & 322 & 100.0 \\
\hline \multirow[t]{4}{*}{ Income Status } & $0-2324 \mathrm{TL}$ & 61 & 18.9 \\
\hline & 2324-6543 TL & 116 & 36.0 \\
\hline & 6543 TL \& More & 145 & 45.0 \\
\hline & Total & 322 & 100.0 \\
\hline
\end{tabular}

Table 3. Findings of the Study of the Relationship Between the Psychological Endurance Scale for Adults and the Young Schema Scale

\begin{tabular}{|c|c|c|c|c|c|c|c|}
\hline & $\begin{array}{l}\text { Psychological } \\
\text { Endurance } \\
\text { Scale for } \\
\text { Adults }\end{array}$ & $\begin{array}{l}\text { Self } \\
\text { Perception }\end{array}$ & $\begin{array}{l}\text { Perception } \\
\text { of the } \\
\text { Future }\end{array}$ & $\begin{array}{l}\text { Structural } \\
\text { Style }\end{array}$ & $\begin{array}{l}\text { Social } \\
\text { Competence }\end{array}$ & $\begin{array}{l}\text { Family } \\
\text { Harmony }\end{array}$ & $\begin{array}{l}\text { Social } \\
\text { Resources }\end{array}$ \\
\hline $\begin{array}{l}\text { Emotional } \\
\text { Deprivation }\end{array}$ & $-.334^{* *}$ & $-.189^{* * *}$ & $-.137^{*}$ & $-.208^{* *}$ & $-.260^{* * *}$ & $-.300^{* *}$ & $-.366^{* *}$ \\
\hline $\begin{array}{l}\text { Social Isolation } \\
\text { /Insecurity }\end{array}$ & $-.223^{* *}$ & $-.151^{* *}$ & $-.168^{* *}$ & -0.100 & -0.084 & $-.295^{* *}$ & $-.216^{* *}$ \\
\hline Imperfection & $-.485^{* *}$ & $-.315^{* *}$ & $-.388^{* *}$ & $-.331^{* *}$ & $-.375^{* *}$ & $-.329^{* *}$ & $-.422^{* *}$ \\
\hline $\begin{array}{l}\text { Suppressing } \\
\text { Emotions }\end{array}$ & $-.340^{* *}$ & $-.224^{* *}$ & $-.174^{* *}$ & $-.215^{* *}$ & $-.370^{* *}$ & $-.227^{* *}$ & $-.269^{* * *}$ \\
\hline Nesting/Addiction & $-.418^{* *}$ & $-.311^{* *}$ & $-.318^{* *}$ & $-.341^{* *}$ & $-.276^{* *}$ & $-.291^{* *}$ & $-.342^{* *}$ \\
\hline Abandonment & $-.267^{* *}$ & $-.218^{* *}$ & $-.254^{* *}$ & $-.161^{* *}$ & -0.105 & $-.203^{* *}$ & $-.269^{* *}$ \\
\hline $\begin{array}{l}\text { Resilience in the } \\
\text { Face of Threats }\end{array}$ & $-.272^{* *}$ & $-.211^{* *}$ & $-.225^{* *}$ & $-.168^{* *}$ & $-.122^{*}$ & $-.224^{* * *}$ & $-.275^{* *}$ \\
\hline Failure & $-.446^{* *}$ & $-.372^{* *}$ & $-.408^{* *}$ & $-.298^{* *}$ & $-.270^{* *}$ & $-.313^{* *}$ & $-.354^{* *}$ \\
\hline Pessimism & $-.328^{* *}$ & $-.266^{* *}$ & $-.274^{* *}$ & $-.244^{* *}$ & $-.229^{* *}$ & $-.160^{* *}$ & $-.291^{* *}$ \\
\hline $\begin{array}{l}\text { Insufficient Self- } \\
\text { Control/Self- } \\
\text { Discipline }\end{array}$ & 0.073 & $.157^{* *}$ & 0.043 & -0.030 & $.122^{*}$ & -0.063 & 0.058 \\
\hline Self-Sacrifice & -0.049 & -0.018 & $-.114^{*}$ & -0.057 & 0.032 & -0.089 & -0.012 \\
\hline Punishment & 0.015 & 0.029 & 0.003 & 0.014 & $.131^{*}$ & -0.099 & -0.039 \\
\hline High Standards & 0.018 & 0.051 & 0.012 & 0.008 & 0.076 & -0.066 & -0.017 \\
\hline Approval Seeking & $.179^{* *}$ & 0.061 & 0.053 & $.145^{* *}$ & $.280^{* *}$ & 0.017 & $.185^{* *}$ \\
\hline
\end{tabular}

$* * \mathrm{p}<0.01, * \mathrm{p}<0.05$ Test used: Pearson Correlation Test 
DOI: 10.17148/IARJSET.2021.8977

Table 4. Findings of the Study of the Relationship Between the Interpersonal Relationships Scale and the Young Schema Scale

\begin{tabular}{lll}
\hline & $\begin{array}{l}\text { Nurturing } \\
\text { Relationship Style }\end{array}$ & $\begin{array}{l}\text { Toxic } \\
\text { Relationship Style }\end{array}$ \\
\hline Emotional Deprivation & $-.113^{*}$ & $.290^{* *}$ \\
Social Isolation & 0.088 & 0.093 \\
Imperfection & $-.351^{* *}$ & $.386^{* *}$ \\
Suppressed Emotions & $-.230^{* *}$ & $.251^{* *}$ \\
Nesting/Addiction & $-.231^{* *}$ & $.279^{* *}$ \\
Abandonment & -0.015 & $.185^{* *}$ \\
Resilience in the Face of Threats & -0.072 & $.180^{* *}$ \\
Failure & $-.280^{* *}$ & $.232^{* *}$ \\
Pessimism & -0.023 & $.237^{* *}$ \\
Insufficient Self-Control/Self-Discipline & $.120^{*}$ & 0.048 \\
Self-Sacrifice & 0.080 & 0.034 \\
Punishment & $.148^{* *}$ & -0.057 \\
High Standards & 0.013 & 0.103 \\
Approval Seeking & $.286^{* *}$ & $-.156^{* *}$ \\
\hline
\end{tabular}

$* * \mathrm{p}<0.01, * \mathrm{p}<0.05$ Test used: Pearson Correlation Test

Table 5. Findings of the Study of the Relationship Between the Interpersonal Relationships Scale and the Psychological Endurance Scale for Adults

\begin{tabular}{lll}
\hline & $\begin{array}{l}\text { Nurturing } \\
\text { Relationship Style }\end{array}$ & $\begin{array}{l}\text { Toxic } \\
\text { Relationship Style }\end{array}$ \\
\hline Psychological Endurance Scale for Adults &, $475^{* *}$ &,$- 481^{* *}$ \\
Self Perception &, $312^{* *}$ &,$- 221^{* *}$ \\
Perception of Future &, $338^{* *}$ &,$- 251^{* *}$ \\
Structural Style &, $369^{* *}$ &,$- 422^{* *}$ \\
Social Competence &, $437^{* *}$ &,$- 478^{* *}$ \\
Family Harmony &, $263^{* *}$ &,$- 341^{* *}$ \\
Social Resources &, $382^{* *}$ &,$- 404^{* *}$ \\
\hline
\end{tabular}

$* * \mathrm{p}<0.01, * \mathrm{p}<0.05$ Test used: Pearson Correlation Test

\section{DISCUSSION AND CONCLUSION}

When the literature is examined, it is generally observed that these concepts are investigated together with various variables or just the relationship between two concepts. There are no studies in which these three concepts are investigated together. This study, it was aimed to examine the relationship between Early Deconstructive Schemes, Psychological Resilience, and Interpersonal Relationship Styles.

According to the findings obtained in this study, a weak and positive relationship was found between the approvalseeking scheme and the psychological resilience sub-dimensions. However, a significant negative relationship was found between the other schema fields. These results are consistent with the results of previous studies conducted in the context of Turkey in the literatüre. Sag (2016) in their research, Disconnection/ Rejection, Bruised Autonomy/ Limits autonomy and bruised, and the other individuals with a lower level of resilience early maladaptive schemas as the Orientation, but the high-standards/ Suppressed schemes a negative relationship with psychological endurance is not stated. In addition, it is considered that it may be important to increase the studies that investigate psychological resilience in the context of early-stage maladaptive schemes scope of the literature and to be conducted with different sample groups.

According to another result, it was found that emotional deprivation, imperfection subscales had a positive effect on the toxic relationship style. It was found that the approval-seeking subscale had a positive effect on the nurturing relationship style, and the imperfection, failure, and suppression of emotions subscales harmed the nurturing 


\section{International Advanced Research Journal in Science, Engineering and Technology}

\section{Vol. 8, Issue 9, September 2021}

DOI: 10.17148/IARJSET.2021.8977

relationship style. Kaya (2010) partially supports this study result by finding that negative parental attitudes and related early-stage maladaptive schemes may be more likely that individuals may have negative interpersonal relationship styles in her study. Based on these results, it can be assumed that the activation of early incompatible schemes and negative family behaviors affect interpersonal relationship styles. When this information is considered by the theory of schema therapy, it can be said that the important thing is that people organize their lives in such a way that these schemes are the least active. Because the more negative schemes are active, the higher the level of a person's maladaptive or problematic behavior will increase.

There are some limitations of this study. In this study, only adult individuals living in Istanbul, Muğla and Izmir provinces participated. This research does not give a causal relationship and is based on a relational conclusion. Researchers who will conduct studies on these concepts are advised to keep the universe wider and to do this study in individuals under the age of 18. In addition, having more sociodemographic questions and analyzing them according to other variables will also improve the scope of the study.

\section{REFERENCES}

Masley, S.A, Gillanders, D.T, Simpson, S.G ve Taylor, M.A (2012). A Systematic Review of the Evidence Base for Schema Therapy.. Bilişsel Davranış Terapisi, 41,3,ss. 185-202.

Saygıl,, G. (2014). 'Erken öneme İlişkin Gelişimsel Etmenler İle Psikolojik İyi Hali Arasındaki İlişkide Erken Dönem Uyum Bozucu Şemaların Aracı Rolnün İncelenmesi. Yüksek Lisans Tezi. Hacettepe Üniversitesi Sosyal Bilimler Enstitüsü. Ankara

Ekşi, H ve , Okan,N.(2021). 'Gençlerrde Maneviyat ve Şiddet Eğilimi Arasındaki İlişkide Erken Dönem Uyum Bozucu Şemalarının Moderatör Etkisi'. Bilimname Dergisi, 1,ss. 521-546.

GÖR, N., Yiğit, İ., Kömürcü,B. ve Şenkalertük,İ. (2017).' Geçmişin Mirası ve Geleceğin Haritası: Erken Dönem' . Nesne Psikoloji Dergisi 5.10,ss.197-218.

Tekin, F. (2019).'Üniversite öğrencilerinin öznel iyi oluş düzeyleri ile kişilerarası ilişki tarzları ve algılanan ebeveyn stilleri arasındaki ilişki'. Yüksek Lisans Tezi. İstanbul Arel Üniversitesi Sosyal Bilimler Enstitüsü. İstanbul.

Çelik,A. ve Topkaya , N.(2018).' Üniversite Öğrencilerinde Kişilerarası İlişki Tarzlarının Yordayıcısı olarak Beş Faktörlü Kişilik Özellikleri' . Uluslararası Toplum Araştırmaları Dergisi,9,16,ss.1-22.

Ertürk,İ ve Kaynar,G. (2017). 'Kişilik Bozukluklarında Şema Terapi Yaklaşımı'. Ufuk Üniversitesi Sosyal Bilimler Enstitüsü Dergisi ,6,12,ss.97114.

Küçükmetin, A. (2018). 'Kişilerarası ilişki tarzları ve sosyal desteğin psikolojik ve fiziksel iyi oluştaki rollerinin incelenmesi'. Yüksek Lisans Tezi. Üsküdar Üniversitesi sosyal Bilimler Enstitüsü.

Koç, B. (2014). 'Kişilerarası İlişki Tarzlarının Saldırganlık ile İlișkisi' . Uluslararası Türkçe Edebiyat Kültür Eğitim Dergisi , 3, 4,ss. 160-182.

Batıgün, A ve Şahin ,N. (2009).' Kişilerarası Tarz, Öfke ve Benlik Algısı: Psikopatolojilerde Ortak Ögeler'. Bilimsel Araştırma Projesi Kesin Raporu. Ankara Üniversitesi.

Kavi,E. ve Karakale,B.(2018). 'Çalışan Psikolojisi Açısından Psikolojik Dayanıklık'. HAK-İŞ Uluslararası Emek ve Toplum Dergisi, 7,17,ss.56-77. Brennan, M. A. (2008). 'Conceptualizing Resiliency: An Interactional Perspective for Community and Youth Development' . Child Care in Practice, 14,1 , ss. 55-64.

Gizir, C. A. (2016).' Psikolojik Sağlmalık, Risk Faktörleri ve Koruyucu Faktörler Üzerine Bir Derleme Çalışması'. Türk Psikolojik Danışma ve Rehberlik Dergisi, 3,28,ss.113-128.

Kaya, F. (2010). 'Çocukluk Döneminde Yaşanan İstismarın Kișilerarası İlişki Tarzları Üzerindeki Etkisi: Erken Dönem Uyum Bozucu Şemaların Aracı Rolü. Yüksek LisansTezi.Ankara Üniversitesi Sosyal Bilimler Enstitüsü. Ankara

Basım,H.N ve Çetin,F.(2011). Yetişkinler için Psikolojik Dayanıklık Ölçeğinin Güvenirlik ve Geçerlilik Çalışması . Türk Psikiyatri Dergisi,22, 2,ss.104-114. 